\title{
SYNTHESIS OF GRAPHENE-LIKE STRUCTURES BY A PLASMA-ARC DISCHARGE IN LIQUID NITROGEN
}

\section{R. A. Panteleimonov, T. V. Kryschuk, O. M. Korduban, V. M. Ogenko}

V. I. Vernadskii Institute of General and Inorganic Chemistry of the National Academy of Sciences of Ukraine, Academic Palladin Avenue, 32/34, Kyiv 03142, Ukraine

${ }^{\star} E$-mail: radik20031@gmail.com

Abstract. Using scanning electron microscopy, X-ray photoelectron spectroscopy, and Raman scattering we studied the charge state of matrix and doping element atoms on the surface, morphology, and defects in the structure of graphene-like materials synthesized by plasma-arc discharge in liquid nitrogen.

Keywords: graphene-like structures, graphene, liquid nitrogen, Raman spectroscopy, plasma arc discharge.

INTRODUCTION. Currently, graphenelike structures are an extremely important material that has unique thermal, electrical conductivity, mechanical strength and optical properties. Every year there are more and more publications about their application and unique properties, and this happens in various industries from chemistry to electronics [1].

Dozens of effective methods for obtaining graphene-like structures are already known, but the most popular are still chemical deposition from the gas phase, the method of laser ablation and synthesis in plasma-arc discharge [2]. Each of these methods is unique in its own way and makes it possible to obtain various graphene-like structures, such as carbon nanotubes, single or multilayer graphene-like material, fullerenes. Among these methods, the synthesis in plasma-arc discharge stands out favorably, thanks to which it is possible to reproduce certain carbon-containing structures. In addition, this method has a number of advantages, such as: low energy costs and reagent costs, high purity of the obtained nanoparticles, a small number of additional chemical methods for removing impurities, which in the other two methods are costly and time consuming. This allows one to obtain a high yield of the final product and the possibility of using some processing products as starting reagents [3].

Synthesis in plasma-arc discharge gives a possibility to create extremely high temperatures and pressures in the discharge zone and immediatly stop reactions, which is crucial for the condensation of certain types of carbon structures: fullerenes, nanotubes of different diameters and lengths, shell structures and 
others. As a medium, you can use not only gases but also liquids [4], such as water, emulsions, suspensions, liquid nitrogen. In addition, liquids are more efficient and convenient for obtaining certain graphene-like structures.

It is known that the physicochemical properties of graphene are significantly changed by the introduction into the graphene structure of heteroatoms of a number of elements.

For example, nitrogen can be introduced into the lattice of graphene-like structures in different ways, which are characterized by different configurations of interatomic bonds (graphite-like, pyridine, pyrrole, etc.). Each of the configurations may have different catalytic activity and affect the electronic structure in different ways. Thus, the synthesis of doped graphene with a fixed type of configuration of the dopant or the maximum set of configurations allows you to control the functional characteristics of the material.

Given the close atomic radii and commensurate lengths of the $\mathrm{N}-\mathrm{C}$ and $\mathrm{C}-\mathrm{C}$ bonds, when nitrogen enters the crystal lattice of graphene, almost no vacancies are formed, which promote electron scattering, resulting in a high mobility of charge carriers. Therefore, nitrogen is ideal dopant for graphene and has the most pronounced doping effect among different types of impurities. The presence of nitrogen atoms in graphene also increases the stability of the carbon lattice by $\sim 200{ }^{\circ} \mathrm{C}$ [5].

In general, in the work the task of synthesis of laboratory batches of functional materials promising for use as sensitive elements of sensors and current sources was set.

The work is aimed at the study of graphenelike structures, which are synthesized by the method of plasma-arc discharge in liquid nitrogen.
EXPERIMENT AND DISCUSSION OF RESULTS. Waste plates of various functional products made of compressed thermally expanded natural graphite produced by TM Spetsmash Ltd, Kyiv were used in the synthesis as arc discharge electrodes. It's worth noting that the samples of thermoexpanded graphite synthesized by oxidation (by the method of Hamer and others) from natural graphite already have a purity of more than 99.9\%. It is also possible to expect that the re-condensation of carbon atoms and subsequent separation of graphene planes at thermal shocks and pressures occurring in the arc discharge zone will further improve the purity of synthesized nanoproducts, which is known to be very important for carbon use in current sources [6].

Heat-resistant utensils were used in the work, and liquid nitrogen was used as a dispersion medium. To reduce the effect of arc light radiation on the synthesized carbon structures, a protective screen made of compressed thermoexpanded graphite plates is provided in the structure in the arc discharge zone (fig. 1).

After the evaporation of nitrogen, the dispersion phase of carbon particles remains in the utensils in the form of dry powder.

Further separation of the synthesized carbon nanoparticles by size was performed by sedimentation in water and ethyl alcohol. In the process of preparation of samples for their analysis and subsequent use, the following methods were used: ultrasonic treatment, mixing, centrifugation, coating of nanocarbon materials with drops of dispersion of a certain concentration. The smallest nanoparticles, forming a transparent dispersion medium, were clearly visible on the Tyndall cone and were stable over time. In the aqueous medium, 
a hydrophobic phase is steadily released, which forms a floating film on the water surface.

During drying and evaporation of the dispersion medium, the dispersed phases formed strong films of different porosity, which are further promising for use in sensitive sensors and current sources.

The images of graphene-like particles were obtained using a scanning electron microscope MIRA3 Tescan. The raman spectra were taken at the center of collective use of the Lashkarev Institute of Semiconductor Physics. X-ray photoelectron spectra were studied in the center of collective use of V.I. Vernadsky IZNH of the National Academy of Sciences of Ukraine.

Figure 1 shows a diagram of an experimental setup for the synthesis of carbon structures. The distance between the electrodes required for the ignition of arc and its stable combustion was $2-4 \mathrm{~mm}$.

In the process of synthesis, graphene-like structures with different structural morphology were obtained.

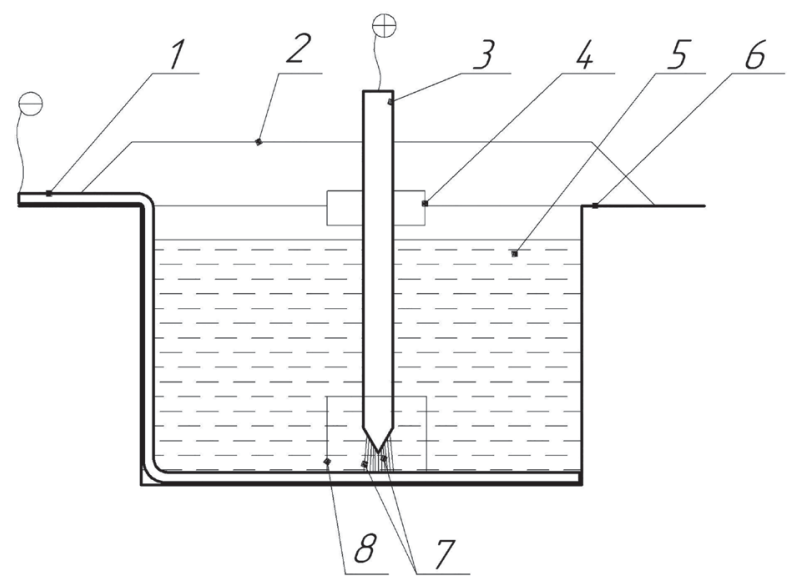

Figure 1 - Schematic diagram of synthesis in plasma-arc discharge: 1 - cathode, 2 - cover, 3 anode, 4 - anode clamp, 5 - liquid nitrogen, 6 - vessel body, 7 - electric arc, 8 - protective screen in the arc zone.

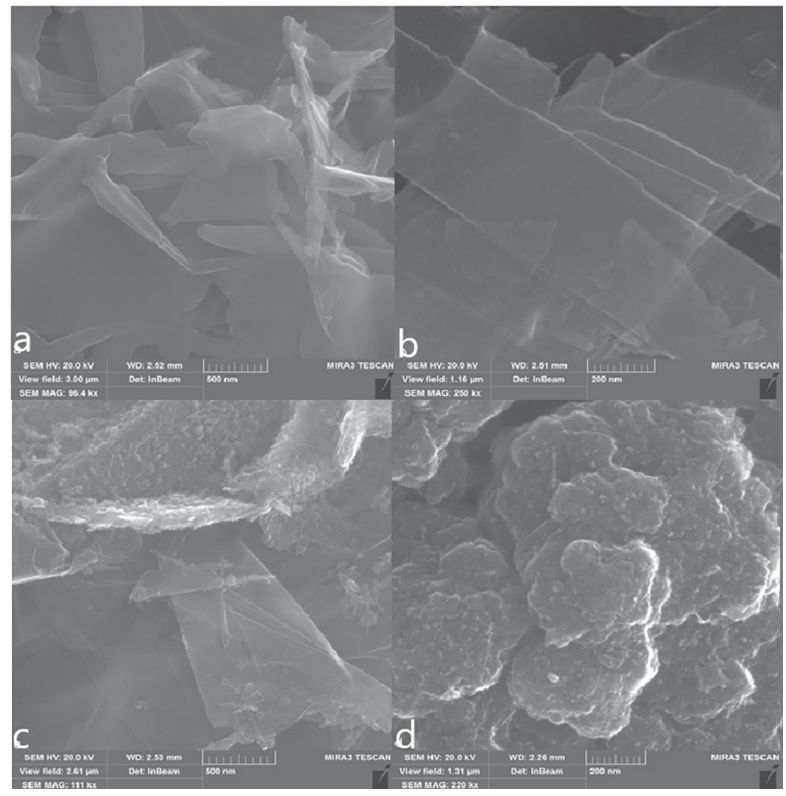

Figure 2 - SEM Image of graphene-like structures: a) cone-shaped carbon nanostructures; b) graphene strips; c) agglomerates of graphenelike structures; d) graphene-like globules deposited on the cathode during synthesis.

Figure 2, shows and examples of the formation of conical structures with an inner diameter of 50 to $150 \mathrm{~nm}$. These particles are illuminated by the probing electron beam of the microscope, making it possible to conclude that they consist of several layers. Figure 2, b shows strips of graphene with a thickness in the range of 5-10 nm. Figure 2, c shows different in shape agglomerates of graphene-like structures. Figure 2, d shows the carbon structures deposited on cathode in the form of globules.

We assumed that in the process of arc discharge in liquid nitrogen, plasma chemical reactions take place between nitrogen radicals and carbon structures.

The electronic structure of the internal $\mathrm{C} 1 \mathrm{~s}$ and N1s levels of the synthesized nanostructures was studied by X-ray photon-electron 
spectroscopy (fig. 3-6). Decomposition into spectral components was performed by the Gauss-Newton method in the mode of bound parameters. The intensity of the components and their binding energy varied. The total width of the components $\Delta \mathrm{E}=1.4 \mathrm{eV}$ and the Gauss-Lorentz contribution ratio $\mathrm{G} / \mathrm{L}=0.7$ during the spectrum decomposition were fixed. The appearance of transparent and absorbing carbon-containing phases was recorded in the visible range of the dispersion medium. According to the XPS, C1s-line, which is decomposed into components (fig. 3-4), along with the contribution of $\mathrm{sp}^{2} \mathrm{C}-\mathrm{sp}^{2} \mathrm{C}\left(\mathrm{E}_{\mathrm{zv}}=284.8 \mathrm{eV}\right)$, characteristic of graphene, contains a component with $\mathrm{E}_{\mathrm{zv}}=$ $286.4 \mathrm{eV}$, which is attributed both to the bond of nitrogen-modified graphene $\mathrm{sp}^{3} \mathrm{C}-\mathrm{N}$ and to the $\mathrm{CO}$ bond [7]. The contribution to the $\mathrm{C} 1 \mathrm{~s}$ line in the energy range with $\mathrm{E}_{\mathrm{zv}}=287.3 \mathrm{eV}$ refers to the $\mathrm{C}=\mathrm{O}$ bond, which is absent in the C1s spectrum of a transparent phase in the optical range.

In the N1s spectra, depending on the local configuration, different chemical shifts are observed. Thus, on the N1s-bands (fig. 5-6) there are components characteristic of nitrogen-modified graphene with $\mathrm{E}_{\mathrm{zv}}=398.4 \mathrm{eV}$ (pyridine-N), $\mathrm{E}_{\mathrm{zv}}=400.0 \mathrm{eV}($ pyrrole- $\mathrm{N})$, $\mathrm{Ezv}=401.6 \mathrm{eV}($ graphite- $\mathrm{N}), \mathrm{E}_{\mathrm{zv}}=402.7 \mathrm{eV}$ (oxidized NO) [8]. It should be noted that in general, the first three of the above configurations are noted in the literature.

The component in the region of $398.4 \mathrm{eV}$ can also be attributed to the nitrile- $\mathrm{N}$ group, where nitrogen is covalently bonded to a carbon atom and two hydrogen atoms [9]. The pyrrole- $\mathrm{N}$ component may also be an $\mathrm{N}$-substitution in the Stone-Wales defect or part of an amine, pyridine, nitroso or cyano group [10].
In this case, the infrared spectra of the samples show bands characteristic of $\mathrm{C}=\mathrm{C}$ and $\mathrm{C}=\mathrm{O}$ vibrations $\left(1630,1650\right.$ and $1736 \mathrm{~cm}^{-1}$ for $\mathrm{C}=\mathrm{C}$ in the sp ${ }^{2}$ state $), \mathrm{C}-\mathrm{O}\left(1375 \mathrm{~cm}^{-1}\right), \mathrm{O}-\mathrm{C}-\mathrm{O}$ $\left(1260 \mathrm{~cm}^{-1}\right)$.

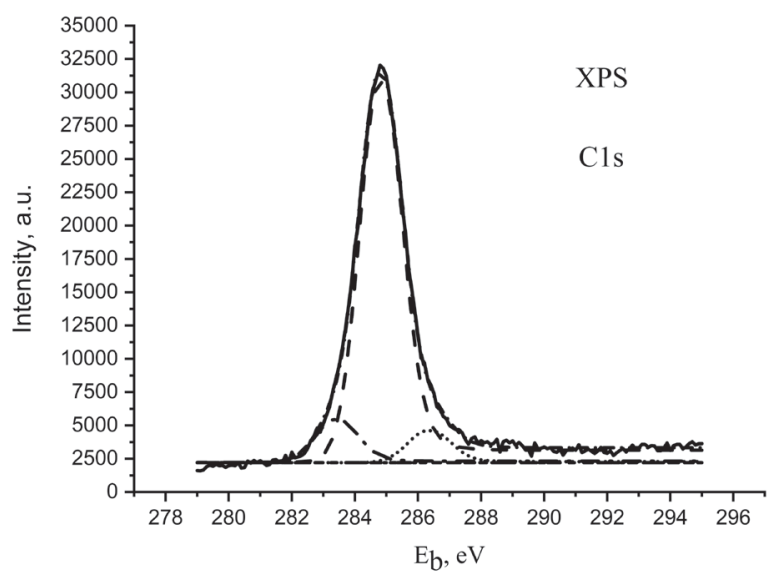

Figure 3 - 1s X-ray photoelectron spectrum of transparent phase carbon.

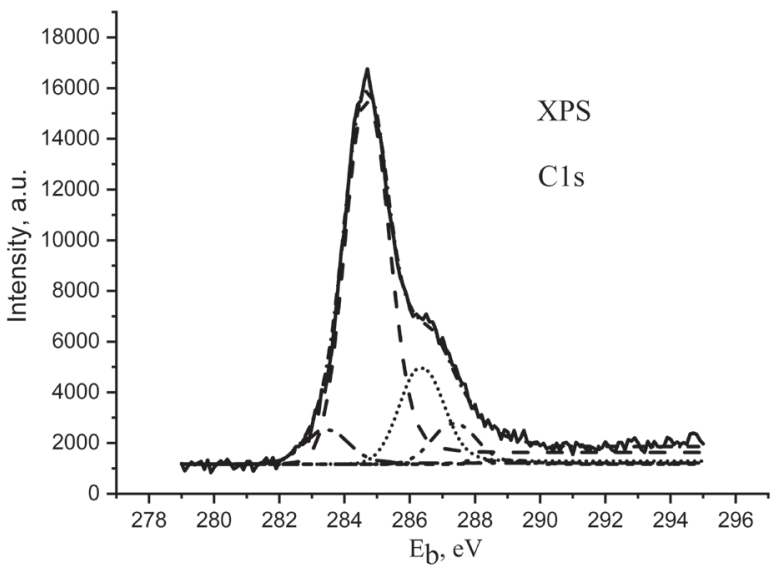

Figure 4 - 1s X-ray photoelectron spectrum of absorbing phase carbon.

In the Raman spectra (fig. 7) there are two main peaks: a G-line $\left(1580 \mathrm{~cm}^{-1}\right)$, which refers to the vibrations of the system of $\mathrm{sp}^{2}$-carbon bonds, and a $2 \mathrm{D}$-line $\left(2670 \mathrm{~cm}^{-1}\right)$, which corresponds to the vibrational states, of defective hexagonal lattice. For the synthesized 
graphene-like structures, a symmetrical sharp peak of the $2 \mathrm{D}$ line is observed, while for thermally expanded and compressed graphite, a broadened peak is shifted to the long-wavelength region with respect to graphene. The degree of structural perfection of graphene can be assessed by the ratio $\mathrm{I}_{\mathrm{D}} / \mathrm{I}_{\mathrm{G}}$. In our case, the $\mathrm{I}_{\mathrm{D}} / \mathrm{I}_{\mathrm{G}}$ ratio is 0.064 for curve 1 and 0.060 for curve 2 , and, consequently, a decrease in the value of the $I_{D} / I_{G}$ ratio indicates an increase in the degree of perfection of the structure of graphene-like nanostructures [11].

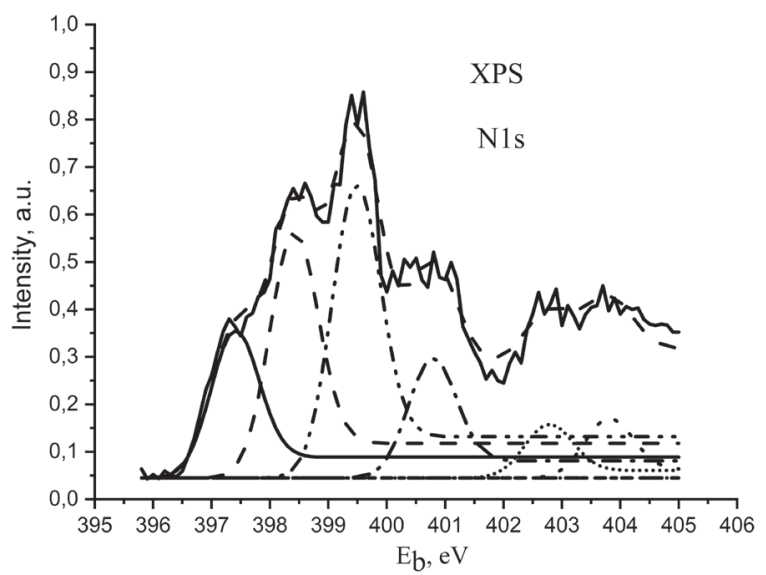

Figure 5 - 1s X-ray photoelectron spectrum of transparent phase nitrogen.

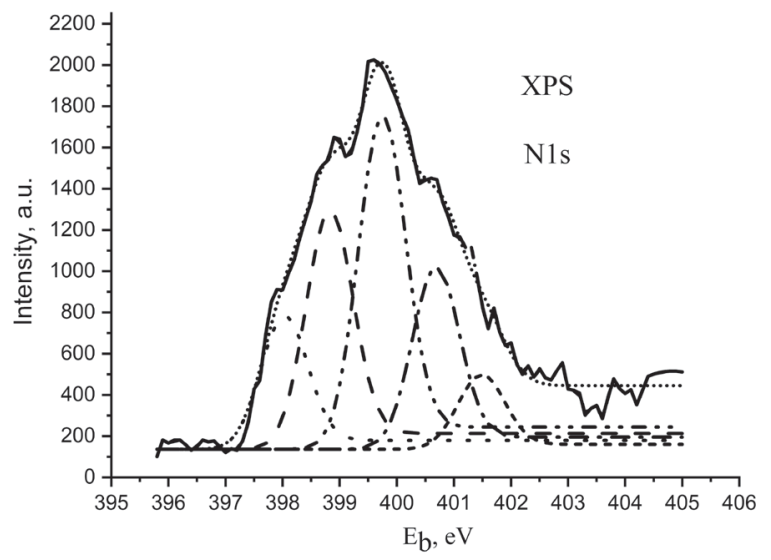

Figure 6 - 1s X-ray photoelectron spectrum of absorbing phase nitrogen.
The morphology and physicochemical characteristics of the obtained samples allow one to use them both individually and in combinations in the form of films in sensors, current sources, supercapacitors, reinforcing polymer fillers, electromagnetic screens and more.

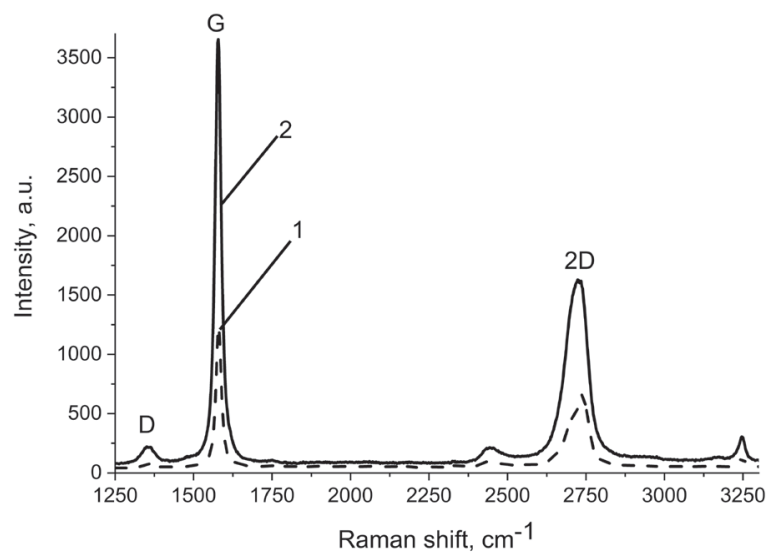

Figure 7 - Spectra of Raman scattering: 1 thermally expanded and compressed graphite; 2 graphene-like structures obtained after synthesis.

\section{CONCLUSIONS.}

Various graphene-like nanostructures doped with nitrogen were synthesized by plasma-arc discharge in liquid nitrogen. Their electronic structure, morphology and structural defects have been studied.

New centers of nitrogen doping of the surface of graphene-like nanostructures are characterized by the method of X-ray photoelectron spectroscopy.

\section{Acknowledgment}

Made according to the theme: GDR 314-E "Physical and inorganic chemistry of functionally oriented systems, heterostructures and composites". 
СИНТЕЗ ГРАФЕНОПОДІБНИХ СТРУКТУР

ПЛАЗМО-ДУГОВИМ РОЗРЯДОМ

У СЕРЕДОВИЩІ РІДКОГО АЗОТУ

Р. А. Пантелеймонов, Т. В. Крищук, О. М. Кордубан, В. М. Огенко

Інститут загальної та неорганічної хімії ім. В. І. Вернадського НАН Украӥни, просп. Академіка Палладіна, 32/34, Київ 03142, Україна

*e-mail: radik20031@gmail.com

Методами скануючої електронної мікроскопії, рентгенфотоелектронної спектроскопії, комбінаційного розсіювання досліджено зарядовий стан атомів матриці та легуючого елементу на поверхні, морфологію та дефекти структури графеноподібних матеріалів, синтезованих плазмо-дуговим розрядом у середовищі азоту.

Ключові слова: графеноподібні структури, графен, середовище рідкого азоту, спектроскопія комбінаційного розсіювання, плазмо-дуговий розряд.

СИНТЕЗ ГРАФЕНОПОДОБНЫХ СТРУКТУР ПЛАЗМО-ДУГОВЫМ РАЗРЯДОМ В СРЕДЕ ХИДКОГО АЗОТА

Р. А. Пантелеймонов, Т. В. Крищук, О. М. Кордубан, В. М. Огенко

Институт общей и неорганической химии им. В. И. Вернадского НАН Украины, просп. Академика Палтадина, 32/34, Киев 03142, Украина

*e-mail: radik20031@gmail.com
Методами сканирующей электронной микроскопии, рентгенфотоэлектронной спектроскопии, комбинационного рассеивания исследовано зарядовое состояние атомов матрицы и легирующего элемента на поверхности, морфологию и дефекты структуры графеноподобных материалов, синтезированных плазмо-дуговым разрядом в среде жидкого азота.

Ключевые слова: графеноподобные структуры, графен, среда жидкого азота, спектроскопия комбинационного рассеяния, плазменно-дуговой разряд.

\section{REFERENCES}

1. Avouris Phaedon Graphene: Electronic and Photonic Properties and Devices // IBM T. J. Watson Research Center, Yorktown Heights, New York 10598, United States. Nano Lett. 2010. 10: 4285-4294.

2. Gubin S. P., Tkachev S. V. Graphene and materials based on it // Radioelectronics | Nanosystems Information Technology. 2010. 2: 99-137.

3. Shmalko, V. M. Keush, L. G. Zelenskiy, O. I. (2018) Nanomaterialy iz uglya i produktov ego piroliza [Nanomaterials from coal and its pyrolysis products], Lira, Dnipro, Ukraine.

4. Nosulenko V. I. Electric arc in a transverse flow of a dielectric medium as a heat source for new technologies // ELECTRICAL PROCESSES IN ENGINEERING AND CHEMISTRY. 2005. 41 (2): 26-33. 
5. Usachev D. Yu., Fedorov A.V., Vilkov O. Yu., Senkovsky B. V., Adamchuk V. K., Andryushechkin B. V., Flabby D. V. Synthesis and electronic structure of graphene doped with nitrogen atoms // Solid State Physics. 2012. 55(6): 1231-1237.

6. Korobko D. I., Khomenko V. G., Barsukov V. Z., Makeeva I. S. Influence of impurities and methodology of their determination in graphite as in the active material of lithium-ion current sources // KNUTD Bulletin. 2015. 86(3): 43-49.

7. Chowdhury F. A., Hossain M. A., Uchida K., Tamura T., Sugawa K., Mochida T., Otsuki J., Mohiuddin T., Boby M. A., Alam M. S. Graphene oxide/carbon nanoparticle thin film based IR detector: Surface properties and device characterization /AIP Advances. 2015. 5; https://doi. org/10.1063/1.4935042 2015.

8. Nakajima T. G., Fujisawa K., Anil V., Terrones M., Yeh Y.-T. Controlling Nitrogen Doping in Graphene with Atomic
Precision: Synthesis and Characterization Nanomaterials. 2019. 9(3): 425; https://doi. org/10.3390/nano 9030425 .

9. Schiros T., Nordlund D., Pálová L., Prezzi D., Kim K. S., Wurstbauer U., Gutiérrez C., Zhao L., Delongchamp D., Jaye C. et al. Connecting Dopant Bond Type with Electronic Structure in N-Doped Graphene. Nano Lett. 2012. 12: 4025-4031.

10. Susi T., Pichler T., Ayala P. X-ray photoelectron spectroscopy of graphitic carbon nanomaterials doped with heteroatoms. Beilstein J. Nanotechnol. 2015, 6: 177-192.

11. Konakova R. V., Kolomys A. F., Okhrimenko O. B., Strelchuk V. V., Volkov E. Yu., Grigoriev M. N., Svetlichny A. M., Spiridonov O. B. Comparative characteristics of the Raman spectra of graphene films on conductive and semi-insulating $6 \mathrm{H}-\mathrm{SiC}$ substrates // Physics and Technology of Semiconductors. 2013. 47(6): 802-804.

Стаття надійшла 25.09.2020 